\title{
Efektifitas Kombinasi Akupresure dan Minuman Jahe (Zingiber Officinale) terhadap Emesis Gravidarum di Desa Bandar Setia Kecamatan Percut Sei Tuan Kabupaten Deli Serdang
}

\author{
Nikmah Jalilah Ritonga ${ }^{1, *}$, Fahma Shufyani ${ }^{2}$, Elsaria Br.Sembiring ${ }^{3}$ \\ ${ }^{1}$ Fakultas Kebidanan (FK), Institut Kesehatan Medistra Lubuk Pakam, Lubuk Pakam, 20512, Indonesia \\ ${ }^{2}$ Fakultas Farmasi (FF), Institut Kesehatan Medistra Lubuk Pakam, Lubuk Pakam, 20512, Indonesia \\ ${ }^{3}$ Fakultas Keperawatan dan Fisioterapi (FKF), Institut Kesehatan Medistra Lubuk Pakam, Lubuk Pakam,20512,Indonesia \\ 'Email : ritonganikmah@yahoo.com* ; ${ }^{2}$ Email : fahmaapotekerunand@yahoo.com ; 3Email : elsariasembiring21@gmail.com \\ * corresponding author
}

ARTICLE INFO

Keywords

Accupressure

Ginger drinks

Emesis Gravidarum

\begin{abstract}
Emesis gravidarum is a common complaint made in young pregnancies. Preganancy causes hormonal changes in women due to an increase in estrogen, progesteron, and the realease of the placental chorionic gonodothropine hormone. Emesis gravidarum usually occurs in the morning, but there are those that arise at any time of the night. Feelings of nausea are caused by increased levels of the hormones estrogen an human chorionic gonadothropine (hCG) in the serum. The purpose of this study was to determine the effect of giving a combination of acupressure and ginger drinks at Bandar Setia Village 2020. This type of research is quantitative research, using a quasy experiment design study with the design of Three-Groups Pretests-Posttest design control. The study population was pregnant women who experienced emesis gravidarum in Desa Bandar Setia. Sampling using Probability Sampling technique that is Simple Random sampling by determining the inclusion and exclusion criteria of 45 pregnant women who will be divided into three groups, 15 people for the experimental group who were given acupressure only, 15 people for the experimental group who were given ginger drinks only, and 15 experimental groups were given a combination of acupressure and ginger drink. The results of the study using Wilcoxon test obtained $\mathrm{p}$-value $=0.000<0.05$. The conclusion is there is an effect on pregnant women who experience emesis gravidarum after being given a combination of acupressure and ginger drink.
\end{abstract}

\section{Pendahuluan}

Sebagian besar ibu hamil trimester 1 mengalami kasus mual muntah. Pada tahun 2012 angka kejadian mual muntah di dunia mencapai 10-14\% dari 790.000 jiwa (WHO, 2013). Angka kejadian mual muntah pada ibu hamil di Indonesia sebesar 14,8\% dari seluruh kehamilan [5].

Mual muntah dialami sekitar $50-90 \%$ wanita, $60-80 \%$ terjadi pada primigravida dan 40-60\% pada multigravida, serta hanya $25 \%$ mual tanpa disertai muntah. Angka mual pada ibu hamil terjadi $70 \%-85 \%$, dan setengah dari persentase ini mengalami muntah. Gejala ini menjadi lebih berat pada seratus dari seribu kehamilan [4].

Ibu hamil mengalami berbagai perubahan baik secara fisik, biologis, maupun psikologis. Perubahan secara fisik seperti bentuk tubuh berubah, secara biologis seperti sering buang air kecil dan secara psikologis ibu hamil mudah marah atau sensitif. Pada kondisi hamil, ibu hamil akan mengalami perubahan hormonal, yaitu meningkatknya kadar hormon estrogen yang menyebabkan ibu mengalami mual dan muntah (emesis gravidarum). Bagi kebanyakan wanita hamil, emesis gravidarum dapat bertahan lebih lama, bahkan hampir selama sembilan bulan kehamilan. emesis gravidarum dapat menyebabkan dehidrasi yang dapat membahayakan ibu dan janin [28]. 
Mual (nausea) dan muntah (emesis gravidarum) adalah gejala yang wajar dan sering terdapat pada trimester 1 kehamilan. Mual biasanya terjadi pada pagi hari, tetapi dapat juga timbul setiap saat dan malam hari. Gejala-gejala ini kurang lebih terjadi 6 minggu setelah hari pertama haid terakhir (HPHT) dan berlangsung selama kurang lebih 10 minggu [17].

Emesis gravidarum biasanya terjadi pada pagi hari, tetapi ada yang timbul setiap saat dan malam hari. Perasaan mual disebabkan oleh meningkatnya kadar hormon estrogen dan human chorionicgonadotropin (hCG) dalam serum. Hormon hCG merangsang produksi estrogen dalam ovarium. Peningkatan hormon estrogen dapat merangsang peningkatan keasaman lambung yang membuat ibu hamil merasa mual. Beberapa peneliti menyebutkan emesis gravidarum disebabkan faktor psikologis, seperti kehamilan yang tidak diinginkan, perasaan marah, bersalah, cemas, dan ketakutan dapat menambah keparahan mual muntah [11].

Emesis gravidarum yang tidak teratasi akan berlanjut menjadi hiperemesis gravidarum yang keluhannya mual dan muntah hebat lebih dari 10 kali sehari dan dapat menyebabkan kekurangan cairan serta penurunan berat badan sehingga mengganggu aktivitas sehari-hari dan membahayakan janin dalam kandungan. Hiperemesis jarang menyebabkan kematian, tetapi angka kejadiannya masih cukup tinggi. Hampir 25\% pasien hiperemesis gravidarum dirawat inap lebih dari sekali, apabila terjadi terus menerus dan sulit sembuh membuat pasien depresi, bahkan ibu hamil sampai merasa ingin mengakhiri kehamilannya [13].

Emesis gravidarum memiliki dampak yang signifikan bagi tubuh dimana ibu menjadi sangat lemah, muka pucat dan frekuensi buang air kecil menurun drastis sehingga caira tubuh semakin berkurang dan darah menjadi lebih kental (hemokonsentrasi). Keadaan ini dapat memperlambat peredaran darah sehingga suply oksigen dan makan ke jaringan juga ikut berkurang hal ini dapat menimbulkan kerusakan jaringan yang membahayakan kesehatan ibu dan janin [24].

Emesis gravidarum merupakan hal yang fisiologis, akan tetapi apabila tidak segera diatasi akan menjadi hal yang patologis. Sebagian besar emesis gravidarum dapat diatasi dengan berobat jalan serta pemberian obat penenang dan anti muntah, akan tetapi sebagian kecil wanita hamil tidak dapat mengatasi mual muntah berkelanjutan sehingga mengganggu aktifitas sehari-hari, dan jatuh dalam keadaan yang disebut hyperemesis gravidarum [31].

Mual muntah dapat ditangani secara farmakologi dengan diberikan obat-obatan untuk mengurangi mual muntah seperti Obat anti emetik/vitamin B6, akan tetapi dari obat-obatan tersebut mempunyai efek samping antara lain seperti sakit kepala, diare dan mengantuk. Tidak semua ibu hamil dapat menjalani terapi dengan menggunakan obat-obatan, ada beberapa ibu yang tidak terlalu suka apabila harus mengonsumsi obat-obatan maka pemberian terapi non farmakologis diperlukan. Pengobatan secara non farmakologi atau terapi komplementer yang mempunyai kelebihan lebih murah dan tidak mempunyai efek farmakologi [17].

Akupresur pengobatan yang diterima dengan baik, dengan insiden efek merugikan yang relatif rendah. Penggunaan akupresur dalam kehamilan banyak hasil positif, mudah dilakukan, bebas bahaya, dan dapat dilakukan sendiri pada wanita yang mengalami mual muntah [5]. Penelitian yang dilakukan oleh Rohmah (2018) tentang Pengaruh pemberian terapi akupresur untuk mengurangi mual muntah pada ibu hamil dengan emesis gravidarum dengan desain penelitian true eksperimen pretest posttest control group, teknik pengambilan sampel adalah probability sampling. Rata-rata mual muntah sebelum diberi terapi akupresur 3-4 kali/hari dan pada kelompok kontrol diberi air minum sesuai kebutuhan mengalami mual muntah 3-4 kali/hari, setelah diberi terapi akupresur selama 3 hari frekuensi mual muntah berkurang 1-2 kali/hari dan kelompok kontrol mual muntah berkurang menjadi 2-4 kali/hari dapat disimpulkan ada pengaruh pemberian terapi akupresur untuk mengurangi mual muntah pada ibu hamil dengan emesis gravidarum [23].

Selain menggunakan akupresur, pengobatan secara non farmakalogi dengan minuman jahe juga sudah banyak dilakukan. Jahe yang direbus menggunakan air panas dengan suhu 60-70 derajat celcius mampu mengobati dan mencegah mual muntah yang terjadi saat kehamilan [23].

Beberapa penelitian menggunakan metode randomized controlled trial terhadap efektifitas jahe menyimpulkan bahwa jahe dapat digunakan untuk mengatasi mual muntah pada kehamilan. Penelitian yang dilakukan oleh [24] di Kashan, Iran 279 wanita hamil dilibatkan, analisi menunjukan bahwa total skor mual muntah berkurang 49\%. Jahe lebih efeketif untuk menghilangkan mual dan muntah ringan daripada placebo. Penelitian yang dilakukan di Afrika Selatan yang melibatkan 1278 wanita hamil diberikan jahe, dimana jahe dianggap sebagai obat 
alternatif yang tidak berbahaya dan efektif untuk wanita yang mengalami mual muntah dalam kehamilan [30].

\section{Metode}

Jenis penelitian ini merupakan penelitian kuantitatif, dengan menggunakan studi desain Quasi Experiment dengan desain Three Groups Pretest-Posttest Design Control, yaitu desain penelitian ketiga kelompok yang terdapat pretest sebelum diberi perlakuan dan posttest setelah diberi perlakuan, namun terdapat dua kelompok sebagai kontrol. Dengan demikian dapat diketahui lebih akurat, karena dapat membandingkan dengan diadakan sebelum diberi perlakuan. Setelah beberapa waktu dilakukan posttest pada ketiga kelompok tersebut. Data yang digunakan di dalam penelitian ini adalah menggunakan data primer dan data sekunder. Alat pengumpulan data yang digunakan peneliti yaitu kuesioner Rodhes INVR (Index of Nausea Vomiting and Retching) yang terdiri dari 5 pertanyaan. Analisa data dilakukan dengan uji statistik Paired T-Test.

Populasi penelitian ini adalah Seluruh Ibu hamil yang mengalami emesis gravidarum di Desa Bandar Setia Kabupaten Deli Serdang pada Bulan Juni sampai dengan Agustus 2020. Pengambilan sampel dengan menggunakan tehnik Probability Sampling yaitu Simple Random sampling dengan menentukan kriteria inklusi dan eksklusi sebanyak 45 orang ibu hamil yang akan di bagi menjadi tiga kelompok yaitu 15 orang untuk kelompok eksperiman yang diberikan akupresure saja, 15 orang untuk kelompok eksperimen yang diberikan minuman jahe saja, dan 15 orang kelompok eksperimen yang diberikan kombinasi akupresure dan minuman jahe.

\section{Hasil dan Pembahasan}

\subsection{Hasil analisis Univariat}

a. Karakteristik Responden sebelum perlakuan

Tabel 1. Distribusi Frekuensi Karakteristik Responden Sebelum Perlakuan Berdasarkan Emesis Gravidarum

\begin{tabular}{|c|c|c|c|c|c|c|}
\hline \multirow{2}{*}{$\begin{array}{c}\text { Sebelum } \\
\text { Tindakan }\end{array}$} & \multicolumn{2}{|c|}{ Akupresur } & \multicolumn{2}{|c|}{ Minuman Jahe } & \multicolumn{2}{|c|}{$\begin{array}{l}\text { Akupresur Dan } \\
\text { Minum Jahe }\end{array}$} \\
\hline & $\begin{array}{l}\mathrm{Fr} \\
(\mathrm{N})\end{array}$ & $\begin{array}{c}\text { Percentase } \\
(\%)\end{array}$ & $\begin{array}{l}\mathrm{Fr} \\
(\mathrm{N})\end{array}$ & $\begin{array}{c}\text { Percentase } \\
(\%)\end{array}$ & $\begin{array}{l}\mathrm{Fr} \\
(\mathrm{N})\end{array}$ & $\begin{array}{c}\text { Percentase } \\
(\%)\end{array}$ \\
\hline Tidak Mual Muntah & 0 & 00.0 & 0 & 00.0 & 0 & 00.0 \\
\hline Mual Muntah Ringan & 0 & 00.0 & 0 & 00.0 & 0 & 00.0 \\
\hline Mual Muntah Sedang & 1 & 6.7 & 0 & 00.0 & 2 & 13.3 \\
\hline Mual Muntah Berat & 7 & 46.7 & 8 & 53.3 & 9 & 60.0 \\
\hline Mual Muntah Hebat & 7 & 46.7 & 7 & 46.7 & 4 & 26.7 \\
\hline & 15 & 100.0 & 15 & 100.0 & 15 & 100.0 \\
\hline
\end{tabular}

Berdasarkan tabel di atas, hasil penelitian karakteristik pada 45 responden berdasarkan emesis gravidarumsebelum diberikan tindakan akupresur terdapat mual muntah sedang 1 orang (6.7\%), mual muntah berat dan mual muntah hebat sama banyak terdapat 7 responden $(46.7 \%)$. Pada tindakan sebelum minum jahe mual muntah berat pada ibu hamil sebanyak 8 orang $(53.3 \%)$, dan mual muntah hebat 7 orang (46.7\%). Dan pada mual muntah sebelum akupresur dan minum jahe mual muntah sedang 2 orang (13.3\%), mual muntah berat sebanyak 9 orang $(60.0 \%)$, dan mual muntah hebat sebanyak 4 orang $(26.7 \%)$.

\section{b. Karakteristik Responden sesudah perlakuan}

Tabel 2.Distribusi Frekuensi Karakteristik Responden Sesudah Perlakuan Berdasarkan Emesis Gravidarum

\begin{tabular}{ccccccc}
\hline \multirow{2}{*}{$\begin{array}{c}\text { Sesudah } \\
\text { Tindakan }\end{array}$} & \multicolumn{2}{c}{ Akupresur } & \multicolumn{2}{c}{ Minuman Jahe } & \multicolumn{2}{c}{ Akupresur Dan Minum } \\
\cline { 2 - 7 } & $\mathrm{Fr}$ & Percentase & $\mathrm{Fr}$ & Percentase & Fr & Percentase \\
& $(\mathrm{N})$ & $(\%)$ & $(\mathrm{N})$ & $(\%)$ & $(\mathrm{N})$ & $(\%)$ \\
\hline Tidak Mual Muntah & 5 & 33.3 & 3 & 20.0 & 6 & 40.0
\end{tabular}




\begin{tabular}{lcccccc} 
Mual Muntah Ringan & 5 & 33.3 & 7 & 46.7 & 8 & 53.3 \\
Mual Muntah Sedang & 5 & 33.3 & 5 & 33.3 & 1 & 6.7 \\
Mual Muntah Berat & 0 & 00.0 & 0 & 00.0 & 0 & 00.0 \\
Mual Muntah Hebat & 0 & 00.0 & 0 & 00.0 & 0 & 00.0 \\
\hline \multicolumn{1}{c}{ Total } & 15 & 100.0 & 15 & 100.0 & 15 & 100.0 \\
\cline { 2 - 7 }
\end{tabular}

Berdasarkan tabel 2 di atas, penelitian emesis gravidarumpada 45 responden setelah pemberian tindakan akupresur terdapat perubahan dimana tidak mual muntah, mual muntah ringan dan mual muntah sedang masing-masing terdapat 5 orang (33.3\%). Pada pemberian minuman jahe juga terjadi perubahan, ibu yang tidak mual muntah terdapat 3 orang (20.0\%), mual muntah ringan sebanyak 7 orang (46.7\%), dan mual muntah sedang sebanyak 5 responden $(33.3 \%)$. Dan setelah pemberian kombinasi akupresur dan minum jahe tidak mual muntah 6 orang (40.0\%), mual muntah ringan $8 \mathrm{ibu}(53.3 \%)$ dan mual muntah sedang 1 orang $(6.7 \%)$.

Berdasarkan hasil analisis uji Normalitas nilai p-value pada hasil Uji Shapiro-Wilk>0,05, maka artinya data berdistribusi normal. Sehingga peneliti mengasumsikan bahwa penelitian ini menggunakan Uji Bivariat Parametrik One Way Anov.

\subsection{Hasil Analisis Bivariat}

Tabel 3. Perbandingan Intensitas Mual Muntah Pada Responden Kelompok AkupresurKelompok Minuman Jahe serta Kombinasi Akupresur Dan Minuman Jahe

\begin{tabular}{|c|c|c|c|c|c|c|c|}
\hline & & $\mathbf{N}$ & Mean & Std. Deviation & Min & Max & $\begin{array}{c}\text { Uji ANOVAp } \\
\text { Value }\end{array}$ \\
\hline \multirow{4}{*}{ Sesudah Akupresur } & Tidak Mual Muntah & 5 & 1.50 & .707 & 1 & 2 & \multirow{4}{*}{0.049} \\
\hline & Mual Muntah Ringan & 5 & 1.89 & .928 & 1 & 3 & \\
\hline & Mual Muntah Sedang & 5 & 2.50 & .577 & 2 & 3 & \\
\hline & Total & 15 & 2.00 & .845 & 1 & 3 & \\
\hline \multirow{4}{*}{$\begin{array}{l}\text { Sesudah Minuman } \\
\text { Jahe }\end{array}$} & Tidak Mual Muntah & 3 & 2.00 & .000 & 2 & 2 & \multirow{4}{*}{0.007} \\
\hline & Mual Muntah Ringan & 7 & 2.22 & .667 & 1 & 3 & \\
\hline & Mual Muntah Sedang & 5 & 2.00 & 1.155 & 1 & 3 & \\
\hline & Total & 15 & 2.13 & .743 & 1 & 3 & \\
\hline \multirow{4}{*}{$\begin{array}{l}\text { Sesudah Kombinasi } \\
\text { Akupresur Dan } \\
\text { Minuman Jahe }\end{array}$} & Tidak Mual Muntah & 6 & .50 & .707 & 0 & 1 & \multirow{4}{*}{0.006} \\
\hline & Mual Muntah Ringan & 8 & .44 & .527 & 0 & 1 & \\
\hline & Mual Muntah Sedang & 1 & 1.25 & .500 & 1 & 2 & \\
\hline & Total & 15 & .67 & .617 & 0 & 2 & \\
\hline
\end{tabular}

Berdasarkan hasil penelitian diketahui bahwa dari 45 orang responden pada uji one way Anova didapatkan nilai $p$ value pada akupresur 0.049, pada minuman jahe 0.007 dan $p$ value pada kombinasi akupresur dan minum jahe 0.006. yang artinya terdapat penurunan signifikan dimana $p$ value < 0.05 , maka Ha diterima, artinya ada perununan emesis gravidarum setelah diberikan kombinasi akupresur dan minuman jahe.

Beberapa penelitian didapatkan bahwa dosis yang memberikan efek untuk mengurangi mual dan muntah pada kehamilan trimester pertama adalah sebanyak $250 \mathrm{mg}$ jahe diminum 4 kali sehari, dapat diminum dalam bentuk sirup maupun kapsul. Banyak penelitian membuktikan bahwa bubuk jahe sebanyak 1 gram per hari dapat menghilangkan mual yang disebabkan oleh berbagai faktor, akan tetapi tidak boleh melebihi 4 gram per hari [33].

Penelitian lain juga menyebutkan bahwa sebaiknya ibu hamil yang mengalami emesis gravidarum diberikan jahe sebanyai 2,5 gram diiris dan diseduh air panas $250 \mathrm{ml}$ dengan suhu 60 7- derajat celcius ditambah gula 1 sendok makan (10 gram) diminum $2 \times 1$ sehari selama 4 hari.[23]

Penelitian ini sejalan dengan penelitian deny eka, erni rumiyati, desy widyastuti ( tahun 2019 ) yaitu pengaruh terapi komplementer akupresure untuk mengatasi emesis gravidarum dari hasil penelitiannya membuktikan bahwa terhapy komplementer atau non farmakologi juga dapat menjadi alternative terutama terhadap ibu hamil yang tidak dapat mengkomsumsi obat . didukung 
oleh penelitian yang memaparkan bahwa pemberian therapy minuman jahe menunjukkan penurunan morning sickness pada ibu hamil trimester I, sesudah diberikan minuman jahe [37].

\section{Kesimpulan}

Ada pengaruh kombinasi Pijat Akupressure dan minuman jahe pada 15 orang responden yang diberikan terapi kombinasi dengan tingkat kemaknaan nilai p-value $<0.05$

\section{Ucapan Terima Kasih}

Terima kasih kepada Kementerian Pendidikan dan Kebudayaan (Kemendikbud) dan kepada Lembaga Layanan Pendidikan Tinggi Wilayah I (LLDIKTI) serta Desa Bandar Setia Kacamatan Percut Sei Tuan Kabupaten Deli Serdang. Dengan adanya bantuan dari semua pihak, penelitian ini dapat berlangsung dengan baik semoga hasil penelitian ini dapat bermanfaat untuk masyarakat khususnya ibu hamil yang mengalami emesis gravidarum agar terhindar dari komplikasi dan kondisi patologis selama kehamilan.

\section{Referensi}

[1] Alyamaniah. 2014. Efektivitas Jahe Untuk Menurunkan Mual Muntah Pada Kehamilan Trimester I Di Kelurahan Suka Karya Kecamatan Kota Baru. https://media.neliti.com/media/publications/286464-efektivitas-jahe-untukmenurunkan-mual-m-3eab18da.pdf (Diakses Pada 26 Januari 2020)

[2] Agustini S. 2012. Pengetahuan Ibu Hamil Tentang Tanda-Tanda Bahaya Kehamilan Di Wilayah Kerja UPT Puskesmas Cimandala Kecamatan Sukaraja Bogor 2012. http://lib.ui.ac.id/file?file=digital/20314706-S_Sri\%20Agustini.pdf (Diakses pada 23 Februari 2020).

[3] Ahmad, J. 2013. Aneka Manfaat Ampuh Rimpang Jahe Untuk Pengobatan. Yogyakarta: Dandra Pustaka Indonesia

[4] Anais Lacasse, Evelyne Rey, Ema Ferreira, Caroline Morin, And Anick Berard. 2009. Epidemiology Of Nausea And Vomiting of Pregnancy: Prevalence, Severity, Determinants, and The Importance Of Race/Ethnicity. BMC Pregnancy Childbirth 2009; 9: 26. Available from www.PubMed.com(online).

[5] Depkes RI. 2013. Laporan Kasus Mual Muntah. http://www.depkes.go.id/resources/download/pusdatin/profil-kesehatanindonesia/profil-kesehatan-indonesia-2014.pdf (Diakses Pada 17 Desember 2019).

[6] Dewi, L H, dkk, 2017, Pengenalan Ilmu Pengobatan Timur Akupresur Level II KKNI Akupresur Aplikatif Untuk Mengurangi Keluhan Pada Kasus-Kasus Kebidanan,, LKPI Kunci Jemari: P3AI

[7] Fengge, A. 2011. Terapi Akupresur Manfaat dan Teknik Pengobatan. Yogyakarta: Crop Circle Corp.

[8] Holmes, Debbie. 2011. Ilmu Kebidanan. Jakarta : EGC.

[9] Irianto Koes. 2014. Ilmu Kesehatan Masyarakat. Bandung: Alfabet.

[10] Jeffrey S dkk. 2003. Psikologi Abnormal Edisi Kelima Jilid 1. Yogyakarta : Erlangga

[11] Jennifer. 2011. Buku Ajar Patofisiologi. Jakarta : EGC.

[12] Kemenkes. Rencana Strategis Kementerian Kesehatan Tahun 2015-2019. Jakarta: Kementerian Kesehatan RI; 2015

[13] Kevin, dkk. 2011. Diagnosis dan Tatalaksana Emesis Gravidarum. Jakarta : Fakultas Kedokteran UI.

[14]Kumalasari I. 2015. Panduan Praktik Laboratorium dan Klinik Perawatan Antenatal. Jakarta : Salemba Medika. 
[15]Koswara S, dkk. 2012. Panduan Proses Produksi Minuman Jahe. Bogor : IPB.

[16]Kundarti I.F., Dwi Esturing dan Reni. 2015.Efektivitas Pemberian Serbuk Jahe (Zingiber Officinale) Terhadap Tingkatan Mual Muntah Pada Ibu Hamil. Jurnal Ilmu Kesehatan Vol. 10 No. 1. $\quad$ file:///C:/Users/Personal/Downloads/70-1-212-1-1020170614.pdf

[17]Lenan, Sari. 2015. Kesalahan-Kesalahan Selama Hamil. Yogyakarta : Laksana

[18]Manuaba, Ida Bagus Gede. 1998. Ilmu Kebidanan, Penyakit Kandungan, Dan Keluarga Berencana. Jakarta : EGC

[19]Megasari, Miratu dkk. 2015. Asuhan Kebidanan 1. Ed. 1. Cetakan 2. Yogyakarta : Deepublish

[20]Neil-Rose W. 2007. Panduan Lengkap Perawatan Kehamilan. Jakarta : Dian Rakyat.

[21]Peraturan Menteri Kesehatan RI. Peraturan Menteri Kesehatan Nomor 97 Tahun 2014 tentang Pelayanan Kesehatan Masa Sebelum Hamil, Masa hamil, Persalinan, dan Masa Sesudah Melahirkan, Penyelenggaraan Pelayanan Kontrasepsi, Serta Pelayanan Kesehtan Seksual

[22]Putri, Ayu. 2016. Efektifitas Pemberian Jahe Hangat Dalam Mengurangi Frekuensi Mual Muntah Pada Ibu Hamil Trimester I. Prosiding Seminar Nasional IKAKESMADA "Peran Tenaga Kesehatan dalam Pelaksanaan SDGs"

[23]Putri, Ayudia. 2019. Pengaruh Pemberian Minuman Jahe (Zingiber Officinale Var. Rubrum) Terhadap Penurunan Emesis Gravidarum Trimester Pertama. file:///C:/Users/Personal/Downloads/Pengaruh Pemberian Minuman Jahe Zingiber Officinal\%20(1).pdf.

[24]Rofi'ah, S. (2019). Studi Fenomologi Kejadian Hiperemesis Gravidarum pada Ibu Hamil Tromester I. file:///C:/Users/Personal/Downloads/598-Article\%20Text-1620-210-20191228.pdf.

[25]Sasmito, E. 2017. Imunomodulator Bahan Alami. Bandung : ANDI OFFSET.

[26]Sunarti. 2013. Asuhan Kehamilan. Jakarta : In Medika.

[27]Sukanta, Oka. Putu. (2003). Akupresur dan Minuman untuk Mengatasi Gangguan Kesehatan Reproduksi. Jakarta: EGC.

[28]Sugeng. 2014. Smart research. Ponorogo: UMPO Press.

[29]Tiran. 2009. Penangangan Emesis Gravidarum Pada Ibu Hamil. https://prosiding_penangananemesisgravidarum_universitasmuhammadiyahsidoarjo.p $\underline{\mathrm{df}}$

[30]Viljoen, E. Visser, J. Koen, N. Musekiwa, A. (2014). ). A Systematic Review And MetaAnalysis Of The Effect And Safety Of Ginger In The Treatment Of PregnancyAssociated Nausea And Vomiting. Nutrition Journal.

[31]Widyastuti Eka. 2019. Jurnal Kebidanan Indonesia. file:///C:/Users/Personal/Downloads/248-443-1-SM.pdf (Diakses pad 26 Januari 2020)

[32]World Health Organization (WHO). 2013. Maternal Database In World https://www.who.int/gho/publications/world health statistics/EN WHS2013 Full.pdf

[33]Wiraharja, Regina Satya. Heidy, Selfi Rustam, Marissa Iskandar. 2011. Kegunaan Jahe Untuk Mengatasi Gejala Mual dalam Kehamilan. DAMIANUS Journal of Medicine. Vol. 10, No.3, Oktober 2011 hal 161-170

[34]Yulistiana, Evayanti, 2015. Hubungan Pengetahuan Ibu Dan Dukungan Suami Pada Ibu Hamil Terhadap Keteraturan Kunjungan Antenatal Care (Anc) Di Puskesmas Wates Lampung Tengah Tahun 2015. Jurnal Kebidanan Vol 1, No 2, Juli 2015: 81-90.

[35]Yuliana. 2015. Dukungan Suami Pada Ibu Hamil Dalam Menghadapi Masa Persalinan Di Desa Joho Kabupaten Sukoharjo. Jurnal.Kebidanan.dan.Ilmu.Kesehatan.Volume2/Nomor2/November2015 
[36]Zhion, 2011, Ginger-Its Value In Human Health -Side Effects And Benefits. Tersedia Online [17 November] (https://www.zhion.com/herb/Ginger.html).

[37]Deny Eka, et all. Terapi Komplementer Akupressure untuk mengatasi emesis gravidarum pada ibu hamil trimester I Tahun 2018. 